\title{
Physiological Characteristics and Deoxyribonucleic Acid Relatedness of Human Isolates of Streptococcus bovis and Streptococcus bovis (var.)
}

\author{
ROYCE G. KNIGHT ${ }^{1 *}$ AND DAVID M. SHLAES ${ }^{1,2.3}$ \\ Laboratory Service, ${ }^{1}$ Research Service, ${ }^{2}$ and Infectious Diseases Section, ${ }^{3}$ Cleveland Veterans Administration Medical \\ Center and Case Western Reserve University School of Medicine, Cleveland, Ohio 44106
}

\begin{abstract}
The current classification of Streptococcus bovis is problematic. Many bovine strains, including the type strain, are not typical of $S$. bovis strains derived from humans, especially in physiologic characteristics. Further, a number of strains physiologically resembling some $S$. intermedius (MG) strains carry the group D antigen and have been classified as $S$. bovis (var.) strains. In this work, we compared the physiologic characteristics and deoxyribonucleic acid relatedness of human strains of $S$. bovis and $S$. bovis (var.), the bovine type strain, and selected bile-tolerant, esculin-hydrolyzing strains of viridans streptococci. Our results indicate a lack of relationship between strains derived from humans and the bovine $S$. bovis type strain. Although, like the classic $S$. bovis strains of human origin, the bovine type strain was able to hydrolyze starch, it differed from human $S$. bovis strains in that it failed to form acid from mannitol and melibiose. The $S$. bovis (var.) strains did not hydrolyze starch or form acid from mannitol. They were distinguished from the bile-tolerant, esculin-hydrolyzing $S$. intermedius (MG) strains by their inability to decarboxylate arginine, their ability to form acid from melibiose, and their production of the Lancefield group D antigen. All $S$. bovis strains of human origin, including the $S$. bovis (var.) strains, formed a single deoxyribonucleic acid homology group distinct from the bovine type strain. Further, none of the $S$. bovis strains were homologous to the $S$. intermedius (MG) or $S$. salivarius strains studied. Our findings suggest that $S$. bovis (var.) forms a subspecies of strains of human origin and that $S$. bovis strains derived from humans should be removed from the $S$. bovis taxon.
\end{abstract}

Streptococcus bovis has been reported as the causative agent of meningitis, septicemia, and endocarditis in humans $(4,6,8,10)$. It also has a strong association with neoplasia of the gastrointestinal tract in humans $(6,11,12,17)$. Thus, the correct identification of $S$. bovis isolates is important in clinical microbiology laboratories.

The classification of $S$. bovis on the basis of phenotypic characteristics has led to several problems. First, S. bovis shares several physiologic properties with bile-tolerant, esculin-hydrolyzing species of viridans streptococci, such as some $S$. intermedius $(\mathrm{MG})$ and $S$. salivarius strains $(3,18)$. Second, Facklam $(2,3)$ has defined a group of human isolates which carry the group D antigen as $S$. bovis (var.) or $S$. bovis II, for which a taxonomic status remains to be established. Third, some classic bovine strains (7), including the type strain (ATCC 33317), are not typical of most human isolates. Unfortunately, the medical literature usually does not distinguish between $S$, bovis and $S$. bovis (var.), probably because they are both bile tolerant and hydrolyze esculin but do not grow in $6.5 \% \mathrm{NaCl}$. Thus, the usual clinical laboratory screening tests would identify both as $S$. bovis. Some bile-tolerant, esculin-hydrolyzing strains of viridans streptococci would also be misclassified as $S$. bovis by these criteria.

Garvie and Bramley (7) studied the physiologic properties and deoxyribonucleic acid (DNA) relatedness of a number of bovine isolates of $S$. bovis. All these strains were homologous, even though some were mannitol fermenting and others were not. Klipper-Balz and co-workers (13) studied the DNA-DNA and DNA-ribosomal ribonucleic acid homologies of two $S$. bovis strains. In their work, neither physiologic characteristics nor strain origin were specified. They noted a close relationship between one of their $S$. bovis

\footnotetext{
* Corresponding author.
}

strains and a strain of $S$. equinus. No studies of the DNA relatedness of the variant strains of Facklam (2) have been published to our knowledge.

Because of the limited published data on human isolates of $S$. bovis, which in some cases appear conflicting $(7,13)$, and because of the lack of information on the DNA relatedness of the variant strains of Facklam (2), we carried out the studies presented here. This work represents a study of the physiologic characteristics and DNA relatedness of reference human strains obtained from R. Facklam, Centers for Disease Control, Atlanta, Ga., and the type strain ATCC 33317 (originally isolated from bovine dung) obtained from the American Type Culture Collection, Rockville, Md., as well as human wild isolates from a variety of sources. We also used a few bile-tolerant, esculin-hydrolyzing viridans strains for comparison.

(This work was presented in a preliminary form at the 85th Annual Meeting of the American Society for Microbiology, Las Vegas, Nev., 3 to 7 March 1985 [R. G. Knight, D. M. Shlaes, and L. Messineo, Abstr. Annu. Meet. Am. Soc. Microbiol. 1985, R20, p. 214].)

\section{MATERIALS AND METHODS}

Bacterial strains. The bacterial strains used in this study are listed in Table 1. Both phenotypic tests and DNA hybridizations were performed.

Phenotypic tests. The phenotypic traits used to characterize the organisms are shown in Table 2. The tests for hemolysis, bile esculin $(40 \%$ bile tolerance and production of esculetin), $6.5 \% \mathrm{NaCl}$ tolerance (salt tolerance), and inulin were performed by the conventional methods described by Facklam (2). The Minitek (BBL Microbiology Systems, Cockeysville, Md.) disk method was used to detect acid production from lactose, D-mannitol, sorbitol, sucrose, raf- 
TABLE 1. Bacterial strains used in this study

\begin{tabular}{|c|c|c|}
\hline $\begin{array}{l}\text { Homology } \\
\text { group }\end{array}$ & Strain & Source and comments ${ }^{a}$ \\
\hline $\mathrm{I}$ & S. bovis ATCC $33317^{\top}$ & ATCC; cow dung \\
\hline \multirow[t]{10}{*}{ II } & S. bovis BM4 & $\begin{array}{l}\text { University Hospital, } \\
\text { Cleveland, Ohio; } \\
\text { human }\end{array}$ \\
\hline & S. bovis F-1867 & $\begin{array}{l}\text { Veterans Administra- } \\
\text { tion Medical Cen- } \\
\text { ter, Cleveland, } \\
\text { Ohio; human blood }\end{array}$ \\
\hline & S. bovis CDC $3437-70$ & $\begin{array}{l}\text { CDC (R. Facklam); } \\
\text { human }\end{array}$ \\
\hline & S. bovis CDC $2482-90$ & $\begin{array}{l}\text { CDC (R. Facklam); } \\
\text { human }\end{array}$ \\
\hline & S. bovis Vitek 1616 & $\begin{array}{l}\text { Vitek Systems, Inc., } \\
\text { Hazelwood, Mo.; } \\
\text { human }\end{array}$ \\
\hline & S. bovis (var.) CDC $663-82$ & $\begin{array}{l}\text { CDC (R. Facklam); } \\
\text { human }\end{array}$ \\
\hline & S. bovis (var.) Vitek 1479 & $\begin{array}{l}\text { Massachusetts Gener- } \\
\text { al Hospital, Boston, } \\
\text { Mass., strain ob- } \\
\text { tained from Vitek } \\
\text { Systems, Inc.; hu- } \\
\text { man }\end{array}$ \\
\hline & S. bovis (var.) CDC 1723-81 & $\begin{array}{l}\text { CDC (R. Facklam); } \\
\text { human blood }\end{array}$ \\
\hline & S. bovis (var.) CDC 2266-81 & $\begin{array}{l}\text { CDC (R. Facklam); } \\
\text { human blood }\end{array}$ \\
\hline & S. bovis (var.) CDC $2460-71$ & $\begin{array}{l}\text { CDC (R. Facklam); } \\
\text { human blood }\end{array}$ \\
\hline \multirow[t]{3}{*}{ Ungrouped } & S. salivarius $\mathrm{F}-882$ & $\begin{array}{l}\text { Veterans Administra- } \\
\text { tion Medical Cen- } \\
\text { ter, Cleveland, } \\
\text { Ohio; human blood }\end{array}$ \\
\hline & S. intermedius ATCC $27335^{\mathrm{T}}$ & $\begin{array}{l}\text { ATCC; W. E. C. } \\
\text { Moore VPI 3372A, } \\
\text { A. Prevot 1877, } \\
\text { neotype, anaerobic }\end{array}$ \\
\hline & S. intermedius (MG) F-1482 & $\begin{array}{l}\text { Veterans Administra- } \\
\text { tion Medical Cen- } \\
\text { ter, Cleveland, } \\
\text { Ohio; human blood }\end{array}$ \\
\hline
\end{tabular}

"ATCC, American Type Culture Collection; CDC, Centers for Disease Control.

finose, and melibiose as described by Setterstrom et al. (19). Arginine dihydrolase (Moeller method) and esculin broth hydrolysis tests were performed by conventional methods (5). A modification of the Barritt method for the VogesProskauer test was used (16). The inoculated methyl redVoges-Proskauer medium was incubated for $48 \mathrm{~h}$ at $35^{\circ} \mathrm{C}$ instead of $24 \mathrm{~h}$ and allowed to stand for $30 \mathrm{~min}$ after the reagents were added to detect acetoin production. The hydrolysis of starch was determined by flooding the surface of a Mueller-Hinton agar plate with Gram iodine $48 \mathrm{~h}$ after inoculation and incubation (16). A zone of hydrolysis appeared colorless, and a dark-blue to purple color indicated that the starch had not been hydrolyzed. The presence of group D antigen was determined by the Phadebact Strep D coagglutination test (Pharmacia Diagnostics, Piscataway, N.J.), and the Streptex test (latex test) for streptococcal grouping (Wellcome Reagents Div., Burroughs Wellcome Co., Research Triangle Park, N.C.) was used to detect other Lancefield group antigens.
Growth and lysis of cells. Each strain was grown in 1.5 liters of Trypticase soy broth (BBL Microbiology Systems) for 18 to $24 \mathrm{~h}$ at 35 to $37^{\circ} \mathrm{C}$ in 5 to $10 \% \mathrm{CO}_{2}$ to the late logarithmic or stationary phase. The cells were harvested by centrifugation at $13,000 \times g$ at $5^{\circ} \mathrm{C}$ with a Sorvall model $\mathrm{RC} 5 \mathrm{~B}$ refrigerated centrifuge. The pellet was suspended in $100 \mathrm{ml}$ of a 1:5 dilution of saline-ethylenediaminetetraacetate buffer $(0.15 \mathrm{M} \mathrm{NaCl}, 0.01 \mathrm{M}$ sodium ethylenediaminetetraacetate $[\mathrm{pH} \mathrm{8.0]).} \mathrm{Lysozyme} \mathrm{was} \mathrm{added} \mathrm{to} \mathrm{a} \mathrm{final} \mathrm{concentra-}$ tion of $0.1 \mathrm{mg} / \mathrm{ml}$, and the mixture was incubated at $37^{\circ} \mathrm{C}$ for 2 to $3 \mathrm{~h}$. "Lyseability" was assayed by removing a small sample, bringing the buffer to full-strength salineethylenediaminetetraacetate, and then adding $20 \%$ sodium dodecyl sulfate to a final concentration of $1 \%$. Lysis was indicated by a rapid increase in viscosity and a change in the suspension from turbid to opalescent. This method is essentially that described by Johnson (9).

Extraction of DNA. DNA was extracted by the method of Marmur and Doty (14) as described by Johnson (9).

DNA base composition. The guanine-plus-cytosine contents of the DNA preparations were calculated from their thermal melting points by the method of Marmur and Doty (15). Escherichia coli $\mathrm{K}-12$ served as the standard.

Preparation of labeled DNA. DNA was labeled in vitro with $\left[{ }^{3} \mathrm{H}\right]$ thymidine $5^{\prime}$-triphosphate (New England Nuclear Corp., Boston, Mass.) and a commercially available nick translation kit (Bethesda Research Laboratories, Inc., Gaithersburg, Md.). The radiolabeled DNA was precipitated with ice-cold ethanol and centrifuged in a 1.5-ml Eppendorf reaction tube. The supernatant was removed, and the precipitate was dried for $30 \mathrm{~min}$ in a vacuum desiccator. The DNA was then suspended in $0.1 \times \mathrm{SSC}(1 \times \mathrm{SSC}$ is $0.15 \mathrm{M}$ $\mathrm{NaCl}$ plus $0.015 \mathrm{M}$ sodium citrate [ $\mathrm{pH} 7.0]$ ) and stored at $-20^{\circ} \mathrm{C}$.

DNA homology assays. Both labeled and unlabeled DNAs were sheared by two 15-s bursts with a sonicator (Heat Systems-Ultrasonics, Inc., Plainsview, New York) and a microtip probe at an energy setting of 22 . The DNA was then denatured by being heated in a boiling water bath for 5 to 10 min and quick-cooled in an ice bath. The assay was performed by mixing $10 \mu \mathrm{l}$ of sheared denatured labeled DNA and $50 \mu \mathrm{l}$ of sheared denatured heterologous DNA $(0.4$ $\mathrm{mg} / \mathrm{ml})$ in $50 \mu \mathrm{l}$ of $0.88 \mathrm{M} \mathrm{NaCl}-10^{-3} \mathrm{M}$ HEPES $(N-2$ hydroxyethylpiperazine- $N^{\prime}$-2-ethanesulfonic acid) buffer (pH 7). All reassociation mixtures were incubated for 20 to $24 \mathrm{~h}$ in $1.0-\mathrm{ml}$ Eppendorf vials submerged in a $60^{\circ} \mathrm{C}$ water bath. After incubation, a $100-\mu l$ portion was removed from each tube and placed in a test tube ( 12 by $75 \mathrm{~mm})$ containing $1 \mathrm{ml}$ of assay buffer $(0.05 \mathrm{M}$ sodium acetate, $0.03 \mathrm{M} \mathrm{NaCl}$, $0.5 \mathrm{mM} \mathrm{ZnCl} 2$ [pH 4.6]) and $50 \mu \mathrm{l}$ of sheared denatured salmon sperm DNA $(0.4 \mathrm{mg} / \mathrm{ml})$. The contents were mixed with a Vortex-Genie (Scientific Indistries Inc., Springfield, Mass.), and $50 \mu \mathrm{l}$ of S1 nuclease (Calbiochem-Behring, La Jolla, Calif.) was added immediately before incubation in a $50^{\circ} \mathrm{C}$ water bath for $1 \mathrm{~h}$. An equal volume of cold $10 \%$ trichloroacetic acid was added to each tube after incubation, and the mixture was placed in a refrigerator $\left(2\right.$ to $\left.6^{\circ} \mathrm{C}\right)$ for at least $1 \mathrm{~h}$. The precipitates were collected on nitrocellulose filters, dried, placed in scintillation vials, and counted. Each experiment was performed in duplicate with a control of unlabeled homologous DNA and a control of unlabeled heterologous (salmon sperm) DNA. Homology was calculated by using the number of S1 nuclease-resistant counts per minute in the homologous reaction as the $100 \%$ value. The value for a background filter (placed in a scintillation vial) and the number of $S 1$ nuclease-resistant counts per 
TABLE 2. Phenotypic test results

\begin{tabular}{|c|c|c|c|c|c|c|c|c|c|c|}
\hline \multirow{2}{*}{$\begin{array}{l}\text { Homology } \\
\text { group }\end{array}$} & \multirow{2}{*}{ Strain } & \multirow{2}{*}{ Hemolysis" } & \multirow{2}{*}{$\begin{array}{l}\text { Hydrolysis } \\
\text { of starch }\end{array}$} & \multicolumn{5}{|c|}{ Acid production from: } & \multirow{2}{*}{$\begin{array}{l}\text { Arginine } \\
\text { dihydro- } \\
\text { lase }\end{array}$} & \multirow{2}{*}{$\begin{array}{l}\text { Lancefield } \\
\text { group }\end{array}$} \\
\hline & & & & Mannitol & Sorbitol & Inulin & Raffinose & Melibiose & & \\
\hline I & S. bovis ATCC $33317^{\mathrm{T}}$ & Alpha & + & - & - & + & + & - & - & $\mathrm{D}$ \\
\hline \multirow[t]{10}{*}{ II } & S. bovis BM4 & Gamma & + & + & - & - & + & $\mathrm{ND}^{\prime}$ & ND & $\mathrm{D}$ \\
\hline & S. bovis F-1867 & Gamma & + & + & + & + & + & + & - & D \\
\hline & S. bovis CDC $3437-70$ & Gamma & + & + & + & + & + & + & - & $\mathrm{D}$ \\
\hline & S. bovis CDC 2482-90 & Gamma & + & + & + & + & + & + & - & $\mathrm{D}$ \\
\hline & S. bovis Vitek 1616 & Alpha & + & + & - & + & + & + & - & $\mathrm{D}$ \\
\hline & S. bovis (var.) CDC 663-82 & Gamma & - & - & - & - & + & + & - & $\mathrm{D}$ \\
\hline & S. bovis (var.) Vitek 1479 & Alpha & - & - & - & - & + & + & - & D \\
\hline & S. bovis (var.) CDC 1723-81 & Alpha & - & - & - & - & + & + & - & $\mathrm{D}$ \\
\hline & S. bovis (var.) CDC 2266-81 & Alpha & - & - & - & - & - & + & - & D \\
\hline & S. bovis (var.) CDC $2460-71$ & Alpha & - & - & - & - & + & + & - & $\mathrm{D}$ \\
\hline \multirow[t]{3}{*}{ Ungrouped } & S. salivarius $\mathrm{F}-882$ & Alpha & - & - & - & + & + & + & - & ND \\
\hline & S. intermedius (MG) F-1482 & Alpha & - & - & - & - & - & - & + & $\mathrm{F}$ \\
\hline & S. intermedius ATCC $27335^{\mathrm{T}}$ & Alpha & - & - & - & - & - & - & + & G \\
\hline
\end{tabular}

"Tested on Trypticase soy base supplemented with 5\% sheep blood (GIBCO Laboratories, Grand Island, N.Y.).

b Determined by the coagglutination test for homology groups I and II and by the latex agglutination test for ungrouped strains.

' ND, Not determined.

minute in the heterologous reaction were subtracted from all counts before homologies were calculated.

The percentage of homologous binding was calculated by dividing the number of counts per minute in a homologous reaction mixture treated with $S 1$ nuclease by those in a homologous reaction mixture not treated with $\mathrm{S} 1$ nuclease.

\section{RESULTS}

Physiologic characterization of strains (Table 2). The following properties were common to all strains tested: esculin hydrolysis, lack of growth in $6.5 \% \mathrm{NaCl}$, production of acid from lactose and sucrose, and production of acetoin in methyl red-Voges-Proskauer medium. All strains, including the wild $S$. salivarius and wild $S$. intermedius (MG) strains, grew in the presence of $40 \%$ bile, as indicated by positive reactions on bile esculin agar. The exception was ATCC 27335 , the type strain of $S$. intermedius, which was negative on bile esculin agar.

Among the $S$. bovis strains, the type strain could be distinguished from all the human isolates by its inability to produce acid from melibiose. It also differed from the starch-hydrolyzing human strains in that it also failed to produce acid from mannitol. The variant human strains failed to hydrolyze starch and did not produce acid from mannitol.

The two S. intermedius (MG) strains tested were able to decarboxylate arginine, a property absent in all $S$. bovis strains tested. Further, all $S$. bovis strains carried the Lancefield group D antigen, whereas $S$. intermedius and $S$. intermedius (MG) strains carried group $\mathrm{G}$ and $\mathrm{F}$ antigens, respectively. The wild $S$. salivarius strain could be distinguished from the $S$. bovis strains by its inability to hydrolyze starch, despite its ability to produce acid from inulin. None of the $S$. bovis strains studied possessed this combination of properties.

Guanine-plus-cytosine content and DNA relatedness. The guanine-plus-cytosine contents of $S$. bovis ATCC $33317^{\mathrm{T}}$ (bovine strain), $S$. bovis (var.) CDC 663-82, and $S$. intermedius ATCC $27335^{\mathrm{T}}$ were $39.0,37.5$, and $36.1 \mathrm{~mol} \%$, respectively. These values were calculated from melting temperatures of $85.3,84.7$, and $84.3^{\circ} \mathrm{C}$, respectively.

Labeled DNAs of $S$. bovis ATCC $33317^{\mathrm{T}}$, S. bovis Vitek
1616, S, bovis (var.) CDC 2266-81, $S$, intermedius ATCC $27335^{\mathrm{T}}$ and $S$. intermedius (MG) F-1482 were used for DNA homology studies (Tables 1 and 3 ). The percentages of homologous binding for these preparations were $66,51,60$, 60 , and $59 \%$, respectively.

Table 3 indicates that the DNA of $S$. bovis ATCC $33317^{\mathrm{T}}$ was not homologous to the DNA of any other strain tested (range, 4 to $44 \%$ ) and therefore formed a homology group of its own. In contrast, the DNA of the human isolate of $S$. bovis Vitek 1616 was homologous to the DNAs of all the other human isolates of $S$. bovis tested, including the $S$. bovis (var.) strains (range, 60 to $100 \%$ ). Further, the DNA of $S$. bovis (var.) CDC 2266-81 was homologous to the DNAs of all the other human isolates of $S$. bovis tested (range, 67 to $100 \%$ ), except for one strain (F-1867), with which it shared only $31 \%$ homology (Table 3 ). This latter result has occurred four times and remains unexplained.

S. intermedius ATCC $27335^{\mathrm{T}}$, which does not tolerate $40 \%$ bile, and $S$. intermedius (MG) F-1482, which does tolerate $40 \%$ bile, showed no homology to any $S$. bovis strain tested (range, 0 to $43 \%$ ) (Table 3). None of the labeled strains used showed significant homology to the bile-tolerant $S$. salivarius DNA used (range 17 to $36 \%$ ) (Table 3 ).

\section{DISCUSSION}

In 1972, Facklam first separated a variant human $S$. bovis isolate from the usual human $S$. bovis isolates (2). This differentiation was based on the inability of the variant strain to hydrolyze starch, form slime in 5\% sucrose agar, or produce acid from mannitol. The variant strain resembles classic $S$. bovis strains in that it is bile tolerant, hydrolyzes esculin, and carries the Lancefield group D antigen. The variant is also similar, however, to a few other bile-tolerant, esculin-hydrolyzing streptococci, such as some $S$. intermedius (MG) and $S$. salivarius strains (3). Since Facklam's original description of this variant among human isolates sent to the Centers for Disease Control, little has appeared in the literature regarding these strains. No taxonomic information regarding the correct classification of these variant strains has been published in the ensuing time period.

In this study, we have attempted to examine the related- 
TABLE 3. DNA relatedness of $S$. bovis and $S$. bovis (var.) and other viridans streptococci

\begin{tabular}{|c|c|c|c|c|c|}
\hline \multirow[b]{2}{*}{ Source of unlabeled DNA } & \multicolumn{5}{|c|}{$\%$ Homology" with ${ }^{3} \mathrm{H}$-labeled DNA from: } \\
\hline & $\begin{array}{c}\text { S. bovis } \\
\text { ATCC } 33317^{\mathrm{T}}\end{array}$ & $\begin{array}{l}\text { S. bovis } \\
\text { Vitek } 1616\end{array}$ & $\begin{array}{c}\text { S. bovis } \\
\text { (var.) } \\
\text { CDC 2266-81 }\end{array}$ & $\begin{array}{c}S . \\
\text { intermedius } \\
\text { ATCC } 27335^{\mathrm{T}}\end{array}$ & $\begin{array}{l}\text { S. intermedius } \\
\text { (MG) F-1482 }\end{array}$ \\
\hline S. bovis (homology group I) ATCC $33317^{\mathrm{T}}$ & 100 & 46 & 17 & 10 & 15 \\
\hline \multicolumn{6}{|l|}{ S. bovis (homology group II) } \\
\hline BM4 & 8 & 100 & 76 & 2 & 12 \\
\hline F-1867 & 37 & 100 & 31 & 0 & 43 \\
\hline CDC $3437-70$ & 44 & 60 & 82 & 0 & 12 \\
\hline CDC 2482-90 & 42 & 62 & 76 & 0 & 14 \\
\hline Vitek 1616 & 37 & 100 & 67 & 0 & 9 \\
\hline \multicolumn{6}{|l|}{ S. bovis (var.) (homology group II) } \\
\hline CDC 663-82 & 27 & 98 & 85 & 7 & 19 \\
\hline Vitek 1479 & 4 & 73 & $\mathrm{ND}^{b}$ & 7 & 11 \\
\hline CDC $1723-81$ & 40 & 68 & 94 & 4 & 14 \\
\hline CDC 2266-81 & 35 & 74 & 100 & 10 & 14 \\
\hline CDC 2460-71 & 35 & 61 & 93 & 36 & 14 \\
\hline S. salivarius (ungrouped) F-882 & 17 & 20 & 22 & 21 & 36 \\
\hline
\end{tabular}

a Data are expressed as averages from at least two experiments.

ND, Not determined.

ness of human isolates of $S$. bovis and $S$. bovis (var.) to each other, to the type strain of $S$. bovis, and to selected representatives of other bile-tolerant, esculin-hydrolyzing strains of streptococci. Our findings indicate that the human isolates of $S$. bovis and S. bovis (var.) that we examined form a single homology group, despite wide differences in physiologic characteristics. Further, the human strains are genetically different from the type strain of bovine origin. Finally, none of the $S$. bovis strains that we examined were related to the few strains of other bile-tolerant, esculin-hydrolyzing streptococci that we studied, including selected strains of $S$. intermedius (MG) and $S$. salivarius.

The $S$. bovis ATCC $33317^{\mathrm{T}}$ bovine cow dung strain is different from the usual human isolates in that it does not produce acid from mannitol. It differs from the human $S$. bovis (var.) strains in that it does hydrolyze starch. Garvie and Bramley (7) studied 11 bovine isolates of $S$. bovis, including the type strain. Six were able to produce acid from mannitol and five were not, although all hydrolyzed starch. All formed a single homology group, with the possible exception of a single mannitol-fermenting strain (7). We suspect that all of these bovine isolates were more similar genetically to the type strain than any of the human isolates and that the mannitol nonfermenting bovine strains are not related to the human $S$. bovis (var.) strains.

In light of our results, it is difficult to interpret the numerical taxonomic study of Bridge and Sneath (1) with regard to $S$. bovis. They studied five strains, none of which was the type strain. Four were grouped into a single phenon and hydrolyzed starch, but only two produced acid from mannitol. The fifth strain was grouped into a separate phenon, which also included $S$. rattus and $S$. mutans.

In their study of streptococcal taxonomy, Klipper-Balz et al. (13) only examined two strains of $S$. bovis. Phenotypic information for the strains was not provided. As determined by DNA-DNA homology, one strain of $S$. bovis was more closely related to their labeled $S$. equinus than to their labeled $S$. bovis. Again, the type strain was not included in their work. Thus, conclusions from their work regarding the taxonomic position of $S$. bovis and $S$. bovis (var.) strains are not possible.
In conclusion, our work presents the first evidence that human isolates of $S$. bovis and $S$. bovis (var.) form a single homology group which is different from that of the $S$. bovis type strain. Thus, the $S$. bovis (var.) strains should be given subspecies status to recognize their physiologic differences from the classic strains of human origin. Further, our findings and those of others suggest that the human strains should be given a taxonomic designation separate from $S$. bovis. We suggest that this could be done by designating a well-characterized human isolate as the neotype strain and naming the human strains separately. We have chosen not to make a formal proposal to resolve this issue on the basis of our current data.

\section{ACKNOWLEDGMENTS}

We thank Richard Facklam and Vitek Systems, Inc., for strains of streptococci and Cherice Edmonds for secretarial assistance.

This work was supported by the Veterans Administration.

\section{LITERATURE CITED}

1. Bridge, P. D., and P. H. A. Sneath. 1983. Numerical taxonomy of Streptococcus. J. Gen. Microbiol. 129:565-597.

2. Facklam, R. R. 1972. Recognition of group D streptococcal species of human origin by biochemical and physiological tests. Appl. Microbiol. 23:1131-1139.

3. Facklam, R. R. 1980 . Streptococci and aerococci, p. 88-110. In E. H. Lennette, A. Balows, W. J. Hausler, Jr., and J. P. Truant (ed.), Manual of clinical microbiology, 3 rd ed. American Society for Microbiology, Washington, D.C.

4. Fikar, C., and J. Levy. 1979. Streptococcus bovis meningitis in a neonate. Am. J. Dis. Child. 133:1149-1150.

5. Finegold, S. M., and W. J. Martin. 1982. Diagnostic microbiology, p. 614-677. C. V. Mosby Co., St. Louis, Mo.

6. Friedrich, I. A., G. P. Wormser, and E. B. Gottfried. 1982. The association of recent Streptococcus bovis bacteremia with colonic neoplasia. Mil. Med. 147:584-585.

7. Garvie, E. I., and A. J. Bramley. 1979. Streptococcus bovis-an approach to its classification and its importance as a cause of bovine mastitis. J. Appl. Bacteriol. 46:557-566.

8. Gavryck, W. A., and F. R. Sattler. 1982. Meningitis caused by Streptococcus bovis. Arch. Neurol. 39:307-308.

9. Johnson, J. L. 1981. Genetic characterization, p. 450-475. In P. Gerhardt, R. G. E. Murray, R. N. Costilow, E. W. Nester, 
W. A. Wood, N. R. Krieg, and G. B. Phillips (ed.), Manual of methods for general bacteriology. American Society for Microbiology, Washington, D.C.

10. Kaplan, M. H., H. Chmel, H.-C. Hsieh, M. J. Tenebaum, I. R. Rothenberg, and G. R. Joachim. 1983. Humoral reactions in human endocarditis due to Streptococcus bovis: evidence for a common $S$. bovis antigen. J. Infect. Dis. 148:266-274.

11. Klein, R. S., M. T. Catalano, S. C. Edberg, J. I. Casey, and N. H. Steigbigel. 1979. Streptococcus bovis septicemia and carcinoma of the colon. Ann. Intern. Med. 91:560-562.

12. Klein, R. S., R. S. Recco, M. T. Catalano, S. C. Edberg, J. I. Casey, and N. H. Steigbigel. 1977. Association of Streptococcus bovis with carcinoma of the colon. N. Engl. J. Med. 297: 800-802.

13. Klipper-Balz, R. G., G. Fisher, and K. H. Schleifer. 1982. Nucleic acid hybridization of group D streptococci. Curr. Microbiol. 7:245-250.

14. Marmur, J., and P. Doty. 1961. A procedure for the isolation of deoxyribonucleic acid from microorganisms. J. Mol. Biol. 3:209-218.

15. Marmur, J., and P. Doty. 1961. Thermal renaturation of DNA. J. Mol. Biol. 3:585-594.

16. Paik, G. 1980. Reagents, stains, and miscellaneous test procedures, p. 1000-1024. In E. H. Lennette, A. Balows, W. J. Hausler, Jr., and J. P. Truant (ed.), Manual of clinical microbiology, 3rd ed. American Society for Microbiology, Washington, D.C.

17. Reynolds, J. G., E. Silva, and W. M. McCormack. 1983. Association of Streptococcus bovis bacteremia with bowel disease. J. Clin. Microbiol. 17:696-697.

18. Ruoff, K. L., and L. J. Kunz. 1982. Identification of viridans streptococci isolated from clinical specimens. J. Clin. Microbiol. 15:920-925.

19. Setterstrom, J. A., A. Gross, and R. S. Stako. 1979. Comparison of Minitek and conventional methods for the biochemical characterization of oral streptococci. J. Clin. Microbiol. 10:409-414. 